\title{
MarTech - Marketing Technology a rozwój platform SaaS do automatyzacji marketingu
}

\author{
MarTech - Marketing Technology in the light \\ of development of marketing automation SaaS platforms
}

\author{
mgr Magdalena Łapińska \\ Szkoła Główna Handlowa, Kolegium Gospodarki Światowej \\ ORCID: 0000-0001-5432-421X \\ e-mail:ml70724@doktorant.sgh.waw.pl
}

\begin{abstract}
Celem opracowania jest zaprezentowanie przykładow wspołczesnych rozwiązań z zakresu automatyzacji marketingu, kierunkow rozwoju technologii w tym zakresie, możliwości, jakie dają przedsiębiorcom, oraz wyzwań, przed jakimi stawiają marketerow. Inwestycja w nowe technologie oraz ich adaptacja stają się koniecznością, a im szybciej przedsiębiorstwa z nich skorzystają, tym większą przewagę konkurencyjną zdobędą. Powszechny dostęp do ogromnych zasobow danych da przewagę tym działom marketingu, ktore je odpowiednio przetworzą przy użyciu technologii i będą stale aktualizować swoją wiedzę w zakresie dostępności nowych rozwiązań MarTech. Wyzwaniem okaże się umiejętność połączenia rożnych technologii pod postacią jednego zintegrowanego systemu, ktory dostarczy holistyczny obraz danych, m.in. na temat konsumenta na jego coraz bardziej skomplikowanej ścieżce zakupowej. To z kolei spowodowane jest otwarciem nowych kanałow komunikacji, jakimi są rozwoj Internetu rzeczy (IoT, Internet of Things) oraz komunikacji wzajemnej urząazeń bez udziału człowieka (machine to machine).
\end{abstract}

Keywords

SaaS, digital marketing, MarTech, ad tech, platform marketingowe, analityka marketingowa, automatyzacja marketingu

The aim of this article is to present examples of modern solutions in the field of marketing automation, directions of technology development in this area, opportunities that it gives to entrepreneurs and the challenges that marketers will have to face. Investment in new technologies and their adaptation is becoming a necessity, and the faster enterprises acknowledge this fact, the more competitive advantage they will gain. Access to huge data resources will give an advantage to those marketing departments that will be able to process it thanks to technology and will constantly update their knowledge regarding the availability of new MarTech solutions. The challenge will be the ability to combine different technologies in the form of a single integrated system that will provide a holistic data image including for instance data about consumers on their even more complex customer journey caused by development of the new communication channels such as IoT (Internet of Things) and communication of devices without human participation M2M (Machine to Machine).

Slowa kluczowe

SaaS, digital marketing, MarTech, ad tech, marketing platforms, marketing analytics, marketing automation

JEL: M300, M390

Str. $17-24$

\section{Bibliografia}

Achrol, R. S. i Kotler, P. (1999). Marketing in the Network Economy. Journal of Marketing, 63, 146-163. https://doi. org/10.1177/00222429990634s114

Ailawadi, K. L. i Farris, P. W. (2017). Managing Multi- and Omni-Channel Distribution: Metrics and Research Directions. Journal of Retailing, 93(1), 120-135. https://doi.org/10.1016/j.jretai.2016.12.003 
Alford, P. i Page, S. J. (2015). Marketing Technology for Adoption by Small Business. The Service Industries Journal, 35(11-12), 655-669. https://doi.org/10.1080/02642069.2015.1062884

Asghar, R. (2014). Study: Millennials Are The True Entrepreneur Generation. Pozyskano z https: //www.forbes.com/ sites/robasghar/2014/11/11/study-millennials-are-the-true-entrepreneur-generation/\#59725e4b73dc

Atkinson, R. D. i McKay, A. S. (2007). Digital Prosperity: Understanding the Economic Benefits of the Information Technology Revolution. The Information Technology \& Innovation Foundation, (3).

Baltes, L. P. (2017). Marketing Technology (Martech) — the Most Important Dimension of Online Marketing. Bulletin of the Transilvania University of Brasov. Economic Sciences, 10(2), 43-48.

Brinker, S. (2018). Marketing Technology Landscape Supergraphic (2018): Martech 5000 (actually 6,829). Pozyskano z https://chiefmartec.com/2018/04/marketing-technology-landscape-supergraphic-2018/

Chang, T. L. (1996). Cultivating Global Experience Curve Advantage on Technology and Marketing Capabilities. International Marketing Review, 13(6), 22-42. https://doi.org/10.1108/02651339610151908

Cook, G. (2014). Customer Experience in the Omni-channel World and the Challenges and Opportunities This Presents. Journal of Direct, Data and Digital Marketing Practice, 15(4), 262-266. https://doi.org/10.1057/dddmp.2014.16

Cusumano, M. (2010). Cloud Computing and SaaS as New Computing Platforms. Communications of the ACM, 53(4), 2729. https://doi.org/10.1145/1721654.1721667

Daj, A., Samoila, C i Ursutiu, D. (2012). Digital Marketing and Regulatory Challenges of Machine-to-Machine (M2M) Communications. Materiały konferencyjne z 9th International Conference on Remote Engineering and Virtual Instrumentation (REV).

Drobiazgiewicz, J. (2018). Omnichannel jako nowoczesny model sprzedaży wielokanałowej. Ekonomiczne Problemy Ustug. $2(131$, t. 2$), 47-54$.

Forbes. (2014). SaaS - czyli przyszłość branży IT. Pozyskano z: https://www.forbes. pl/wiadomosci/saas-czyli-przyszloscbranzy-it/y6ylycv (12.08.2018).

Fulgoni, G. M. (2014). Omni-Channel Retail Insights and The Consumer's Path-to-Purchase. How Digital Has Transformed the Way People Make Purchasing Decisions. Journal of Advertising Research, 54(4), 377-380. https://doi.org/ 10.2501/JAR-54-4-377-380

Gabrielsson, P. i Gabrielsson, M. (2004). Globalizing Internationals: Business Portfolio and Marketing Strategies in the ICT Field. International Business Review, 13(6), 661-684. https://doi.org/10.1016/j.ibusrev.2004.10.001

Grishikashvili, K., Dibb, S., Meadows, M. (2014). Investigation into Big Data Impact on Digital Marketing. Materiały konferencyjne z International Conference on Communication, Media, Technology and Design. Istanbul.

Grossberg, K. A. (2016). The New Marketing Solutions That Will Drive Strategy Implementation. Strategy \& Leadership, 44(3), 20-26. https://doi.org/10.1108/SL-04-2016-0018

InternetWorldStats.com. (2013). Usage and Population Statistics. Pozyskano z https://www.internetworldstats.com/ top25.htm

Jarvinen, J. i Karjaluoto, H. (2015). The Use of Web Analytics for Digital Marketing Performance Measurement. Industrial Marketing Management, 50, 117-127. https://doi.org/10.1016/j.indmarman. 2015.04.009

Kociuba, M. i Dragosz, Ł. (2015). FreshMail/bdsklep.pl. Jak zrobić klientow z nieaktywnych. Dowiedz się, jak długofalowo budować lojalność klientow, jednocześnie zwiększając liczbę nowych zakupow. Marketing w Praktyce, (12), 78-82.

Kung, L., Kroll, A. M., Ripken, B. i Walker, M. (199). Impact of the Digital Revolution on the Media and Communications Industries. Journal of the European Institute for Communication and Culture, 6(3), 29-47.

Lamberton, C. i Andrew, S. T. (2016). A Thematic Exploration of Digital, Social Media, and Mobile Marketing: Research Evolution from 2000 to 2015 and an Agenda for Future Inquiry. Journal of Marketing, 80(6), 146-172. https://doi.org/10.1509/jm.15.0415

Lamberton, C. i Stephen, A. T. (2015). Taking Stock of the Digital Revolution: A Critical Analysis and Agenda for Digital, Social Media, and Mobile Marketing Research. Said Business School WP 2015-16.

Leeflang, P., Verhoef, P., Dahlstrom, P. i Freundt, T. (2014). Challenges and Solutions for Marketing in a Digital Era. European Management Journal, 32(1), 1-12. https://doi.org/10.1016/j.emj.2013.12.001

Li, Y. M., Lai, C. Y. i Chen, C. W. (2011) Discovering Influencers for Marketing in the Bogosphere. Information Sciences, 181(23), 5143-5157. https://doi.org/10.1016/j.ins.2011.07.023

Marinchak, C. M., Forrest, E. i Hoanca, B. (2018) Artificial Intelligence: Redefining Marketing Management and the Customer Experience. International Journal of E-Entrepreneurship and Innovation, 8(2), 14-24. https://doi.org/ 10.4018/IJEEI.2018070102

McKinsey \& Company. (2008). Hal Varian on how the Web challenges managers. Pozyskano z https://www.mckinsey.com/ industries/high-tech/our-insights/hal-varian-on-how-the-web-challenges-managers

Melewar, T. C. i Smith, N. (2003). The Internet Revolution: Some Global Marketing Implications. Marketing Intelligence \& Planning, 21(6), 363-369. https://doi.org/10.1108/02634500310499220 
Merlin, S., Woodcock, D. i David, N. (2014). Interactive, Direct and Digital Marketing: A Future That Depends on Better Use of Business Intelligence. Journal of Research in Interactive Marketing, 8(1), 4-17. https://doi.org/10.1108/JRIM07-2013-0046

Miller, P. (2018). Surviving and Thriving During the Next Marketing Technology Implementation: Best Practices for Modern Marketers. Journal of Brand Strategy, 6(4), 356-361.

Newspoint.pl (2018). Monitoring marki i influencerów. Pozyskano z: https://www.newspoint.pl

PwC. (2017). Digital IQ 2017. Cyfrowy wyścig firm. Pozyskano z https://www.pwc.pl/pl/publikacje/2017/digitaliq2017. html

Radulovich, L. P., Pendleton, G. i Scherer, R. F. (2005). Sustainable Competitive Advantage of Infirms: A Strategic Framework and Implications for Global Marketers. International Marketing Review, 22(6), 658-672. https://doi.org/10.1108/02651330510630276

Rangaswamy, A. i Van Bruggen, G. H. (2005). Opportunities and Challenges in Multichannel Marketing: An Introduction to the Special Issue. Journal of Interactive Marketing, 19(2), 5-11. https://doi.org/10.1002/dir.20037

Rao, P. M. (2001). The ICT Revolution, Internationalization of Technological Activity, and the Emerging Economies: Implications for Global Marketing. International Business Review, 10(5), 571-596. https://doi.org/10.1016/S09695931(01) 00033-6

Shafaghi, M., Woollaston, C. i Lui, V. (2010). B2B e-marketplace: An e-marketing Framework for B2B Commerce. Marketing Intelligence \& Planning, 28(3), 310-329. https://doi.org/10.1108/02634501011041444

Shankar, V. i Winer, R. S. (2005). Interactive Marketing Goes Multichannel. Journal of Interactive Marketing, 19(2), 2-3. https://doi.org/10.1002/dir.20038

Simmons, G. (2008). Marketing to Postmodern Consumers: Introducing the Internet Chameleon. European Journal of Marketing, 42(3/4), 299-310. https://doi.org/10.1108/03090560810852940

Spero, I. i Stone, M. (2004). Agents of Change: How Young Consumers Are Changing the World of Marketing. Qualitative Market Research: An International Journal, 7(2), 153-159. https://doi.org/10.1108/13522750410530057

Stone M. D. i Woodcock N. D. (2014). Interactive, Direct and Digital Marketing: A Future That Depends on Better Use of Business Intelligence. Journal of Research in Interactive Marketing, 8(1), 4-17. https://doi.org/10.1108/JRIM-072013-0046

Sztandera, K. (2015). Co 3 Polak marzy o założeniu własnej firmy. Jak jej prowadzenie pogodzić z etatem? Innpoland. Pozyskano z https://innpoland.pl/120047,co-3-polak-marzy-o-zalozeniu-wlasnej-firmy-jak-jej-prowadzenie-pogodzicz-etatem-oto-5-przydatnych-porad

Wasak, M. (2016). Reklama z ekranu na ekran. Marketing w Praktyce, (1), 66-68.

Wołek, Ł. (2017). Jak dobrze łączyć narzędzie on- i offline. Marketing w Praktyce, (3), 65-67.

Wu, W. W. (2011a). Developing an Explorative Model for SaaS Adoption. An International Journal. Expert Systems with Applications, 38(12), 15057-15064. https://doi.org/10.1016/j.eswa.2011.05.039

Wu, W. W. (2011b). Mining Significant Factors Affecting the Adoption of SaaS Using the Rough Set Approach. Journal of Systems and Software, 84(3), 435-441. https://doi.org/10.1016/j.jss. 2010.11.890

Varadarajan, P. R. i Yadav, M. S. (2002). Marketing Strategy and the Internet: An Organizing Framework. Journal of the Academy of Marketing Science, 30(4), 296-312. https://doi.org/10.1177/009207002236907

Van Bommel, E., Edelman, D. i Ungerman, K. (2014). Digitizing the Consumer Decision Journey. McKinsey \& Company. Pozyskano z https://www.mckinsey.com/business-functions/marketing-and-sales/our-insights/digitizing-the-consumerdecision-journey 